International Journal of English Literature and Social Sciences
Vol-6, Issue-1; Jan-Feb, 2021

\title{
Influence of Teachers' Professional Development Practices on Job Performance in Public Secondary Schools: A Case of Nyamagana District, Mwanza - Tanzania
}

\author{
Eveline Richard Mduma, Demetria Gerold Mkulu
}

Department of Educational Foundation, St. Augustine University of Tanzania, Mwanza, Tanzania

Received: 25 Nov 2020; Received in revised form: 20 Jan 2021; Accepted: 30 Jan 2021; Available online: 09 Feb 2021

(C)2021 The Author(s). Published by Infogain Publication. This is an open access article under the CC BY license

(https://creativecommons.org/licenses/by/4.0/).

\begin{abstract}
The study sought to find out the Influence of Teacher's Professional Development Practices on their Job Performance in Nyamagana District, Mwanza Region. The study employed convergent parallel design under the mixed methods approach to help collect and analyze both quantitative and qualitative data strands. Stratified random sampling and simple random sampling techniques were used to sample public secondary schools and teachers while purposive sampling techniques were used to sample heads of schools and the District Education Officer. Data was collected through the use of questionnaires and in-depth interview guides. The quantitative data was analyzed with the aid of Statistical Package for Social Sciences (SPSS) while qualitative data were analyzed through thematic analysis of the specific objectives. The findings revealed that training the workforce (teachers) has the most impact on different dimensions like; improvement of teaching strategies, reduces teachers' burnout, stress and turnover, improves teachers' effectiveness and improves overall teacher's personnel. Henceforth, regular performance appraisals in schools enable teachers to improve themselves in classroom management, simplifies supervision, evaluation and assessment process, improves proper communication and it also ensures teachers' discipline at work. At last the study recommended that the ministry of education, science and technology, education stakeholders in conjunction with school administrators (district educational officer and heads of schools) to regularly organize and facilitate formative in-service training for teachers to enhance their job performance.
\end{abstract}

Keywords - Influence, Teachers' professional development, Job performance, Management practices, performance appraisal.

\section{INTRODUCTION AND BACKGROUND OF THE STUDY}

Education has been identified to be among of the tool for development. Many countries across the world have built schools for children to learn as well as universities and colleges are being constructed to prepare teachers to teach in schools. It is evident that for any education institution to achieve its goals it must ensure the quality of its teachers by training and re-training them (Paschal, Nyoni and Mkulu,
2020). Many studies conducted in the world have revealed that, it is important for teachers to be developed in ensuring teachers' quality as well as students' academic achievement. Teachers play a vital position in promoting education, learning and professional growth of learners (Paschal, and Mkulu, 2020). As it must be noted that teachers are vital assets in any learning institution; their job performance is very important in determining the extent to which instructional process is enhanced Taylor (1856-1915). As a result, maintaining these unique assets through effective training 
becomes imperative so as to maximize their job performance. Teachers' performance has been an issue at the center of discussion when students and schools performance is under discussion. Teachers' performance can be manifested in improvement in production, easiness in using the new technology and highly motivated workers. Success of any organization depends on the availability of effective and efficient management style that supports both material and human resource mechanism (Kamoche, 2002). It needs a complete managers and concrete management channel to make sure that teachers' job performance upgrade as it determines the effectiveness of the school and the advancement of learners in character.

Byars \& Rue (2006) deliberated on the variable of teachers' management as strategic approach to the effective management of teachers in a school organization such that they help their school management team to gain a competitive advantage. It is designed to maximize teachers' performance in service of an employer's strategic objectives. Teachers' professional development managers are the pillars of the school organizations, thus they are entitled to play various roles including functional role of managing teachers in the school setting, directing, controlling, leading and others. School teaching management is defined as a system of activities and strategies that focus on successfully managing teachers at all levels of the school organization to achieve organizational goals (Byars \& Rue, 2006).

\section{How Teachers' Professional Development Practices Influence their Job Performance?}

Kamoche (2002) viewed the management of teachers in Africa as a quite challenging as most systems have difficulties seeing the correct gauge of human resources. This may partly be the consequence of the different kinds of problems, for instance, political instability, corruption, bureaucracy, inadequate infrastructures, low level of education and purchasing power, diseases and famine known to predominate in the African continent. That is to say, for the human resource management especially in the practice of teachers' professional development, there must be frequently programs to make sure teachers are given the chance to develop themselves so that may bring about the quality education hence higher academic achievement that may results into their better performance. Training the workforce is the crux of better organizational management in a school context, as it makes teachers more efficient and effectual. Also, training the workforce has a strong bond with all other human resources practices. This enables teachers to grow themselves within the organization and raise their market value in education arena as well as to shape their job related behavior in a school organization (Kraak, 2005).

The quality of teachers' job performance in most of public secondary schools nowadays has been put in doubts due to the poor attitudes manifested by several secondary school teachers who appear to be non-committed to their jobs. Some public secondary school teachers do not go to school on time, some rarely teach students, writing notes of the lesson appears a boring task to many teachers who ought to have professional behaved. The truant nature of public secondary school teachers as exhibited in their poor attitude towards instructional duties; lateness to work, inconsistent attendance to school or classes, poor record keeping attitude, and their poor disciplinary attitudes, is a pointer to the fact that many teachers are ineffective in their job performance (Oluwasem, 2016 as cited in Festus, Valentine and Esther, 2019).

Additionally, Afshan (2013) conceptualized that, the quality of teaching workforce needs to be improved in order to enhance the education standards and those standards require improvement through training and professional development of teachers, teachers compensation system, professional career development, and performance management of the teaching workforce. However, school heads are considered as human resource managers who are responsible for enhancing teachers' job performance in school level. "The purpose of Human Resource Management in education is to develop the teachers and to contribute to goal achievement" (Omebe, 2014). So teachers' professional development management plays a crucial role in influencing and improving the efficient and effectiveness of teachers' job performance as well.

Teachers are the most valued assets and truly the pillar of the school organization. Every teacher in his or her own way adds towards the success or failure of the school. Without employees in an organization, even the most powerful machinery with the latest technology would not function. Therefore, employees should not treat their organization as a miserable source of earning money because their job positions are not just to come in the morning, leave in the evening and receive their remunerations. Lastly, employers should not treat their employees as slaves. Employers must invest their time and resources in training and developing their workforce for them to become indispensable resources later. Teachers should well be trained and developed to prepare them to face even the worst situations.

\section{Statement of the Problem}

Teaching and learning does not happen overnight (Paschal, and Mkulu, 2020). It is the process that needs training and 
retaining of the teachers and learners (Paschal, Nyoni, and Mkulu, 2020). In school context teachers are essential assets for effective instructional process. Most of secondary school teachers seem not to perform their tasks effectively in their working station which undermine the teaching profession (Qutoshi \& Khaki as cited in Moos, 2013). For teachers to perform excellently, their managers need to work out their professional development. As the curriculum for secondary education in Tanzania through Education Sector Development Programme (ESDP) has put it clearly that, teachers shall be judged on the basis of school performance and unceasing performance in skills altitude and knowledge. Despite the efforts made by the Government and different education stakeholders to address this situation of employee development, teachers still not performing their duties as required. That means teachers' professional development practices do not favor and upgrade teacher's career that results into their unsatisfied performance. This scenario prompted the researcher to explore the status quo of the teachers' professional development practices and how these practices may influence their job performance in public secondary schools in Nyamagana district, Tanzania.

\section{Purpose of the Study}

The current study aimed to assess the influence of teachers' professional development practices on their job performance in public secondary schools in Nyamagana District, Tanzania. The study focused on the following specific objectives;-

i. To find out the effects of training the workforce on teachers' job performance in public secondary schools in Nyamagana District.

ii. To determine the impacts of performance appraisal on teachers' job performance in public secondary schools in Nyamagana District.

\section{Significance of the Study}

The findings from the current study will be of bring benefit to the government and policy makers, human resource management (quality assurers, DEO's, WEC's, School heads) to carry out their roles very effectively and efficiently towards influencing teachers' job performance in public secondary schools. Moreover, the findings from the current study are intended to provide information to the teachers concerning their commitment, positive perception towards work, good morale, and job satisfaction towards work. In addition to that, the findings of this study will benefit other education stakeholders like community, parents and students and lastly this study will make a foundation for other studies.

\section{Conceptual Framework}

Independent Variables

Teachers' Professional Development Practices

- Performance appraisal

- Professional Career

Development

○ In-service

Training,

Workshops and

Seminars

\section{Dependent Variables}

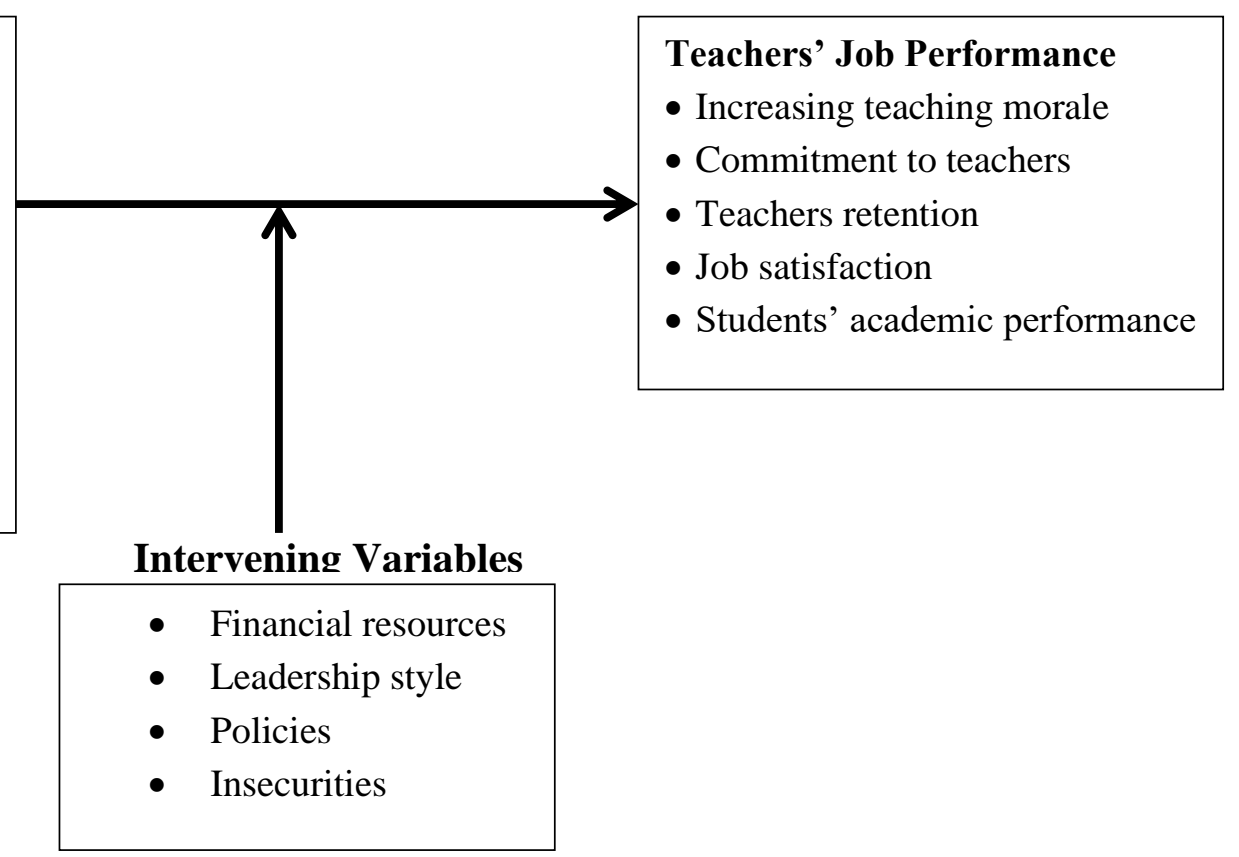

Source: Researcher (2020)

ISSN: 2456-7620 
The conceptual framework above shows how teachers' professional development as a human resource management practice including; performance appraisal, training the workforce, workshops and seminars in connection to financial resources, leadership style, policies and insecurities in influencing teachers' job performance. High teachers' job performance leads to high teaching morale, commitment to teachers, teachers' retention rates, job satisfaction as well as better students' academic performance.

Whereby, whenever on job training is offered in schools, performance appraisal is carried as well, teachers are been given the chance to attend seminars, workshops and further trainings, this will obviously develop and build their skills, hence their job performance will increase whereas it will raise their morale on teaching and also they will be committed to work.. Again, it will increase retention rate of teachers, which means there would be no more teachers' turn over, also they will be satisfied during teaching process and that will raise students' academic performance and the school performance in general.

\section{Theoretical Literature Review}

This study adopted System Theory of organizations which was propounded by Ludwing Von Bertalanffy and William Ross Ashby between 1940 and 1970s and furthered by Ross Ashby in 1964. Von Bertalanffy conceptualized that, system is complex of interacting elements and that they are open to, and interact with their environments. In relation to this study it means that, in order for teachers to carry out their roles as it is required there is a need of cooperation between various departments from national level to school level. Furthermore, Meles, Peles and Poles (2010) argued that, system theory is a theoretical perspective that analyses a phenomenon seen as a whole not a simply the sum as elementary parts. This concur to the current study that institutions like schools has their own system, therefore it is the responsibilities of the human resource management particularly in education arena to carry out their roles effectively so as to enhance good teachers' performance which accelerates the achievement of school intended goals. System theory emphasizes the mutual independence of the parts (input, process and output).

School organizations as open systems that have flexible boundaries that allow communication to flow easily. In connection to this study it means that, organizations like schools depend on the inflow and outflow of information that has great impact on teachers' job performance. In addition to that, the reviewed system theory states that an organization is the combination of parts with interdependent relationships and opens to interaction with the external environment. That means, in order for the organizations like schools to reach its objectives it needs intensive cooperation between education stakeholders who are within the organization and those who are outside the organization.

Moreover, Thien and Abd Razak (2012) documented that, a system theory insists on three mainly interactive elements; input, throughput and output. In relation to this study, it means that institutions are not self-contained that they depend to get inputs from the surrounding environment for instance, students, teachers, financial and moral support to mention a few and then process them and finally give output such as knowledgeable, skilled as well as experienced students who have positive impact to the environment hence system theory will enable to understand the function of each unit in an institution. For example in schools, every teacher has its own department to work on and everybody needs not to interfere with the other to make sure that everybody fulfills their tasks as assigned. Even in human resource management as among the unit that improves and enhances teachers' job performance, has to work as a team to make sure that every department works effectively and efficiently not to break the system as a whole. This theory recognizes various parts of the organization and in particular the interrelations of the parts within an institution. For instance, the coordination of human resource management team with its programs helps to manage conflicts that arise into teachers' working places in a positive way that may bring into harmony in an institution.

Additionally, an open system theory consists of five elements: inputs, a transformation process, outputs, feedback and environment this is according to Scott (2008) as cited in Ludenburg (2010). These elements constantly interact with the external environment, where by the external environment can be understood as political, and social, economic and cultural forces. Also the reviewed theory emphasizes that; external environment is the important factor which determines the organization survival. That is to say organizations/institutions like schools never die but their existence depend much on external environment.

This theory is relevant to the current study as it aims in meaningful analysis of school organization and their management. It insists on analyzing the responsibilities and duties of school management and departments in showing the divisions of functions to each unit. Also the theory focuses on the environment and how changes brought by the environment can impact the school organization. 
Generally, system theory has potential to increase teachers' retention rate as well as their commitment to work as it encourages them and all human resource managers to work in such a way that they cooperate from each other through the given departments to make sure that teachers feel more valued by the school organization hence their better performance.

\section{RELATED LITERATURE REVIEW}

Saifalislam, Osman and AlQudah (2014) conducted a study on the Influence of training, recruitment and selection, and development on the organizational performance of the Jordanian Public University in Malaysia. The study employed quantitative research approach where questionnaire were used as an instrument for data collection, SPSS for coding data as well as descriptive statistics for analyzing and presenting data. The study revealed that training, recruitment and selection are the development influence on employee performance. Finally, the study recommended that there should be a training and management development program so as to enhance the capabilities of employees. That means, in order for any organization to achieve its intended goals there must be well organized programs specifically in recruiting, selecting, training and development of workers (teachers).

On the other hand, Benedict (2012) carried out the study on the employee development practices a panacea to the impacts of the ministry for home affairs in South Africa. The study used mixed research approach and questionnaire were used as an instrument for data collection which involved open ended and closed questionnaire. The study employed SPSS for coding data which were analyzed and presented through descriptive statistics such as graphs and tables. The study found that employees need to be trained, recruited and placed in a way that will facilitate them to utilize their skills and abilities effectively. Henceforth, better performance of any institution including educational institution depends upon the good procedure of recruitment and placement of employees in the right positions in an institution. This study also recommended that organizations should develop a staffing schedule and recruit enough personnel to insure that there is adequate staff at all the time. In relation to this study, public secondary schools should prepare a well-organized timetable and recruit enough teachers so as to meet the schools' needs that will enable the schools to reach the predetermined goals.

Moreover, Wanjara, Wamalwa and Egessa (2014) conducted a study on the effects of training the selected human resource practices on teachers' performance in public primary schools: A case study of Bungoma west sub-county in Kenya. In this study the researcher employed mixed research approach and descriptive correlation survey design. Data were collected through questionnaires and document analysis using frequencies, percentages, coded and tabulated for accuracy, reliability and ease of analysis and presentation using SPSS software program. At last the study found that training has a relationship with teacher's performance, therefore teachers have to be given the chance for them to undergo different kinds of training so as to develop their professions.

Tan and Nasurdin (2011) did a study on teachers' training and Career Development: Assessing the mediating role of knowledge management effectiveness in Malaysia. The study employed questionnaire as well as descriptive statistics such as mean scores and standard deviations in presenting data. The findings of this study showed that training was positively related to organizational dimensions. Also training and performance mediate the relationship between training and process innovations. So in connection to this study human resource management should develop the training program to secondary school teachers so as to increase creativeness and innovations for well attainment of their performance goals. Looking at the previous study, only questionnaire was employed as the method of collecting information which limited the scope of the findings. Therefore the current study filled the gap by using more than one method of data collection such as interview, questionnaire and document analysis so as to have variation of the findings.

Similarly, a study by Hashmi (2014) on the human resource management strategies and teacher's efficiency within schools: A co-relational study in Australia. The study used mixed research approach; also survey was used as a research design. Purposive sampling was used as a technique in obtaining research participants and questionnaire was used as a tool to collect data. The results of the study indicated that, no relationship exists between the organization of the school and the newly acquired knowledge and skills of human resource management. The school leaders are unaware of the various function and strategies which are necessary to promote teachers' efficiency. The study showed that some of the educational leaders are striving to meet the educational requirement of the times and to face challenges which using the learnt strategies of human resource management to promote teachers' efficiency for the improvement of their particular schools.

Moreover, Festus, Valentine and Esther (2019) carried out a study in Akamkpa local government area of cross river state in Nigeria on human resource appraisal and teachers' job performance in secondary schools. The study collected data 
through questionnaire; the study adopted a descriptive survey research design and data were obtained from both primary and secondary sources. The findings from this study revealed that, there is significant relationship respectively between principal's interpersonal relationship, teachers' participation in decision making and principals delegation of responsibilities with teachers' job performance in secondary schools. Based on these findings it was recommended among others that, principals should ensure that they create conducive school climate by building a school interpersonal relationship with teachers in order to improve their job performance. Therefore, teachers should be actively involved in making certain decisions for the school especially those within their jurisdiction in order to foster unity and cooperation in the implementation of such decisions. Looking at the previous study as it was conducted in West Africa specifically in Nigeria, the current study was conducted in Tanzania specifically in Mwanza region. Therefore context gap was filled by showing the similarities and differences of the findings.

Also Chemutai (2017) conducted on the motivation and appraisals of school principals as human resource managers (HRM) in secondary school teachers' in Nandi County, Kenya. A study employed survey research design. Census sampling was used to select the study sample and data was collected through self-administered questionnaires where coding of responses was done by using SPSS for windows 16 . Analysis of the data was done through descriptive statistics and data analyzed was presented in form of frequency, tables and charts. The study discovered that, the principals who are the human resource management are in agreement that human resources courses ought to be introduced in all teachers training college. There is a need of in-service courses for already appointed principals; this is particularly to equip them with knowledge and skills on human resource management. HRM head to insure improvement of curriculum, instruction and other pertinent element of the school. The study also concluded that, there is a need by the MoE to create offices for HRM in the learning institution so that they give support services to the principal's office and other offices within the school. In the end the study recommends provision for room to equip them with HRMs skills either in full before appointment as principals or in-service courses should be compulsory and immediately provided after their appointment. The MoE should provide the principals of secondary schools with in-services courses on HRM after appointment. This should be at the level of diploma or degree in order to equip them fully with adequate knowledge and skills required. Linking to this study regular training are needed to all human resource managers and this course of human resource management should be taught in all levels of education.

Furthermore, in Tanzania, Kajiru (2014) did a study on the effectiveness of appraisal on employee development strategies in local government authorities: A case study of Babati district council. The study employed mixed research approach and a case study design were used. Both probability and non-probability sampling were used where stratified and purposive samplings were employed in the study. Data were collected through interview, questionnaire, participant observation and documentary review and then analyzed by using SPSS and represented by using tables. The study found that local government through the ministry of education, science and technology has to be given autonomy to set and implement their programmes in response to secondary schools' teachers. Also capacity building should be regularly provided to teaching staffs so that they may generate and upgrade their knowledge and skills effectively. That means human resource management should make sure they set goals and implement them on time as they planned to make sure that teachers are frequently upgrade their careers hence their better performance.

\section{RESEARCH METHODOLOGY}

This study adopted mixed methods approach in which both quantitative and qualitative research method. That means both quantitative and qualitative data were collected, analyzed and interpreted in a single study. Creswell (2014) conceptualized quantitative research as an approach for testing objective theories by examining the relationship among variables. Also the current study employed convergent parallel design which enabled the researcher to effective merge qualitative and quantitative data for comprehensive analysis of the research problem. In this design, the researcher collected data from different sources and analyzed them separately and later integrated the results.

\section{Sampling Procedures}

The sample size of this study is 91 and the study employed both probability and non-probability sampling in selecting samples in order to ensure validity and reliability of the study.

\section{Data Collection Methods}

Data collection is an essential element in the production of useful data for analysis and is subject to empirical research informed by theory (Graves et al., 2009). The method of data 
collection used by a researcher depends on the research paradigm that the study employs. Therefore the current study employed primary data collection methods whereby questionnaires (both closed-ended and open open-ended questions), and interview guides were employed to obtain information so as to accomplish the study.

\section{FINDINGS AND DISCUSSION}

The findings obtained from the field accordance with the research objectives posed in chapter one. Data was from collected teachers, HoS and DEO through the use of interview guides and questionnaires. In this section, the researcher was interested in knowing the demographic characteristics of the respondents as follows;

Table 1: Distribution of the Demographic Profile of Teachers ( $n=84)$

\begin{tabular}{llcc}
\hline Demographic Profile & & $\begin{array}{c}\text { Number of Respondents } \\
(\mathbf{n = 8 4})\end{array}$ & $\begin{array}{c}\text { Percentage } \\
(\boldsymbol{\%})\end{array}$ \\
\hline Gender & Male & 51 & 60.71 \\
Age & Female & 33 & 39.29 \\
& $21-30$ years & 46 & 54.76 \\
& $31-40$ years & 25 & 29.76 \\
Highest Education & 41 years and above & 13 & 15.48 \\
Qualification & Diploma & 34 & 40.48 \\
& & & \\
& Bachelor Degree & 41 & 48.81 \\
Working Experience & Master's Degree & 9 & 10.71 \\
& Less than a year & 2 & 2.38 \\
& 1-10 years & 61 & 72.62 \\
& 11-20 years & 17 & 20.24 \\
& Above 20 years & 4 & 4.76 \\
\hline
\end{tabular}

\section{Source: Field Data, (2020)}

\section{Teachers Demographic Distribution by Gender}

The findings in the table 1 above indicate that $51(60.71 \%)$ of the respondents were male teachers while 33(39.29\%) were female teachers. Whereas the study did not treat gender as an extraneous variable to be controlled for, the likelihood that different sexes may prefer different treatment in their duties could be a pointer to variations in commitment to job performance. However, males being not responsible for a lot of other family chores were likely to be more committed in their formal duties in contrast to the female counterparts.

\section{Teachers Demographic Distribution by Age}

The findings in the table 1 depicted that $46(54.76 \%)$ of the respondents were aged between 21-30 years, while $25(29.76 \%)$ were between $31-40$ years and only $13(15.48 \%)$ were of 41 years and above. The study thus concluded that majority of teachers in Nyamagana aged between 21-30 years. This the period within which individuals are not much stable in their jobs and are inclined to seek for employment elsewhere and likely to be committed to their job performance in the hope for promotion. It is the age group that keeps struggling to improve their career to enhance their job performance.

\section{Teachers Demographic Distribution by Education Qualifications}

On the other hand, the researcher believed that level of education would significantly influence individual teacher's commitment to job performance, having been conditioned by strong professional ethics and codes of conducts governing teachers' professional engagement. Findings in table 1 showed that $34(40.48 \%)$ of the teachers had diploma; $41(48.81 \%)$ had bachelor degree in education, and $9(10.71 \%)$ the respondents had master of education degree. The impression created by these statistics is that public secondary school level teaching is that practically all the teachers were professionally qualified and thus they were expected to have a job performance that was above average. Thus the 
presupposition is that teachers were professionally equipped but they need to be committed.

\section{Teachers Demographic Distribution by Working Experience}

Findings given in table 1 show that only $2(2.38 \%)$ of the respondents had an experience of less than a year. The researcher also found out that majority of teachers 61(72.62\%) had an experience that ranged between 1-10 years. $17(20.24 \%)$ had an experience between $11-20$ years and $4(4.76 \%)$ of the teachers had experience between 21-30 years. The findings indicate that the duration of time served in a particular secondary school influenced job performance. In this respect, young/teachers in earlier years of employment tended to commit their time on assigned duties more. Similarly, teachers at the verge of promotion also work hard to achieve the desired promotion. However, teachers whose terms of service have advanced to retirement tended to be either slow or to put little efforts in their duties.

\section{Effects of Training the Workforce on Teachers' Job Performance}

The process of education is generally intricate, consuming a lot of resources and often run into years characterized by myriad threatening challenges, yet its fruits are rarely immediate and conspicuous to the immediate beneficiaries. Besides, education draws individuals in their tender ages, unaware of its benefits posing tremendous bottle necks to teachers in performing their tasks. In order to effectively navigate the difficulties in tasks performance, effective teacher training is crucial to equip them with requisite knowledge and skills necessary for molding a strong crop of young people with the capacity to positively change the society.

Table 2: Respondents Participation in Training $(n=84)$

\begin{tabular}{lcc}
\hline Response & Frequency & Percentage \\
\hline Yes & 76 & 90.48 \\
No & 8 & 9.52 \\
Total & $\mathbf{8 4}$ & $\mathbf{1 0 0}$ \\
\hline
\end{tabular}

Source: Field Data, (2020)

Findings presented in table 2 indicated that $76(90.48 \%$ ) of the respondents had undergone in-service training in their respective public secondary school in Mwanza. 08(9.52\%) of the respondents indicated that they had not gone through any sort of in-service training by the public secondary school for which they work for. This implied that though not all teachers in public secondary schools that had attended the in-service training at least majority of the teachers had participated in the in-service training that equipped them with the necessary knowledge and skills.

\section{Selection of Teacher's for In-service Training}

Respondents were asked to indicate criteria used to select teachers for in-service training by indicating whether; they were selected to attend the training upon joining school; recommended by the heads of school or supervisor, whether it was compulsory for all to attend upon teacher's request or it was part of the performance appraisal. The findings were summarized and presented in table 3 .

Table 3: Selection of Teacher's for In-service Training

\begin{tabular}{lcc}
\multicolumn{3}{c}{$(n=84)$} \\
\hline Criteria & Frequency & Percentage \\
\hline Upon teacher's request & 30 & 35.71 \\
Head's/Supervisor's & 14 & 16.67 \\
recommendation & & \\
Compulsory for all & 24 & 28.57 \\
On joining the school & 7 & 8.33 \\
Performance appraisal & 3 & 3.57 \\
Don't know & 6 & 7.15 \\
Total & $\mathbf{8 4}$ & $\mathbf{1 0 0}$
\end{tabular}

Source: Field Data, (2020)

Findings in table 3 indicated that 30(35.71) had to be trained upon teacher's request while $24(28.57 \%)$ indicated that it inservice training were offered on compulsory basis for all the teachers. Much more 14(16.67\%) of the teachers reported that attendance to in-service teachers training depended on recommendation by school heads or school supervisor (quality assurance officer). However, 7(8.33\%) of the teachers said that they attended the in-service training when on joining the school while $6(7.15 \%)$ of the teachers said that they did not know the criteria used to select teachers for in-service training. Therefore, the study found that utmost teachers were given opportunities to attend in-service training as a part of development practice that impacted teachers' job performance. However, the criteria used to select teachers differed.

\section{Influence of In-service Training on Teachers' Job Performance}

The researcher was interested in finding out whether the teachers' in-service training equipped teachers with knowledge and skills that influenced teachers' job 
performance. The findings obtained from the questionnaires for teachers are summarized and presented in table 4 .

Table 4: Influence of In-service Training on Teachers' Job Performance $(n=84)$

\begin{tabular}{lcc}
\hline Response & Frequency & Percentage \\
\hline Yes & 79 & 94.05 \\
No & 5 & 5.95 \\
Total & $\mathbf{8 4}$ & $\mathbf{1 0 0}$ \\
\hline
\end{tabular}

Source: Field Data, (2020)

Findings in table 4 show that majority of teachers $79(94.05 \%)$ acknowledged that in-service training equipped teachers with knowledge and skills that influenced teachers' job performance. However, a small number of teachers 5(5.95\%) held a contrary opinion. Conclusively, the study found out that in-service training in public secondary schools in Nyamagana district focused on particular knowledge and skills that influence teachers' job performance. These findings are in line with some of the reviewed literature such as; Wright \& Geroy (2001), Swart et al., (2005), Harrison (2000), and Appiah (2010) which affirmed that training the employee influence their performance by empowering them with knowledge and skills.

\section{Effects of Training the Workforce on Influencing Teachers' Job Performance}

The researcher was interested in finding out what were the impacts of training the workforce on influencing teachers' job performance in public secondary schools. The respondents mentioned that training workforce influenced teachers' job performance in ways such as; increasing teaching morale, enhancing teachers' commitment, teachers' retention and improving students' academic performance. These findings were supported by several reviewed literature such as Appiah (2010), Harrison (2000) and Wright \& Geroy (2001) that studied the level of correlation between impacts of employee training and employee's empowerment.

\section{Need for Further Training}

It was relevant to find out whether the teachers felt the need for further training. As such, the researcher asked the teachers to indicate whether they felt any need for further training so as to improve their job performance. The findings are summarized and presented in table 5 .
Table 5: Need for Further Training ( $n=84)$

\begin{tabular}{lcc}
\hline Response & Frequency & Percentage \\
\hline Yes & 73 & 86.90 \\
No & 11 & 13.10 \\
Total & $\mathbf{8 4}$ & $\mathbf{1 0 0}$ \\
\hline
\end{tabular}

Source: Field Data, (2020)

Findings presented in table 5 indicate $73(86.90 \%)$ of the teachers affirmed that they needed further training. Majority of these indicated that based on the nature of their jobs in general, there is ever changing technology which presents ever changing teaching methods for which they have to cope with. Thus, in their opinion calls for frequent training so as to keep up-to-date in all situations. Therefore, it can be implied that, there is a need for teachers to be given the chance to go for further studies as the 86.90 percent of the respondents are replying to the question if there is a need for them to be given the chance for further studies for them to increase teaching skills and develop their careers so that they may increase their job performance.

\section{Effects of Training the Workforce on Teachers' Job Performance}

In the previous sub-sections the researcher wanted to find out if the teachers felt a need for being trained as the workforce and their confirmed that indeed there was that need. In line with these the study through the use of a Likert scale investigated on the effects of training the workforce on teachers' job performance. The findings are summarized and presented in table 6 .

Table 6: Effects of Training the Workforce on Teachers' Job Performance $(n=84)$

\begin{tabular}{lcc}
\hline $\begin{array}{l}\text { Effects of on-job } \\
\text { training }\end{array}$ & Frequency & Percentage \\
\hline $\begin{array}{l}\text { Improved teaching } \\
\text { strategies }\end{array}$ & 20 & 23.81 \\
$\begin{array}{l}\text { Updated teachers } \\
\text { knowledge and skills }\end{array}$ & 14 & 16.67 \\
$\begin{array}{l}\text { Changed teachers } \\
\text { attitude }\end{array}$ & 9 & 10.71 \\
$\begin{array}{l}\text { Helps teachers to } \\
\text { overcome various } \\
\text { instructional challenges }\end{array}$ & 13 & 15.47 \\
\end{tabular}




\begin{tabular}{lcc}
$\begin{array}{l}\text { Reduced teachers } \\
\text { burnout, stress and } \\
\text { turnover }\end{array}$ & 15 & 17.86 \\
$\begin{array}{l}\text { Improved teachers } \\
\text { effectiveness }\end{array}$ & 13 & 15.48 \\
\hline Total & $\mathbf{8 4}$ & $\mathbf{1 0 0}$ \\
\hline
\end{tabular}

\section{Source: Field Data (2020)}

Findings in table 6 indicate that 20(23.81\%) of the teachers said that training the workforce brought about improved teaching strategies. This means that teachers are supposed to get involved in different trainings so that it may improve their methods of teaching that may influence and update their skills hence better performance of the students and it is where (teachers) may improve their academic performance.

Comparably, 15(17.86) said that training the workforce helped in reducing teachers burnout and stress and hence reduced teachers' turnover. Sometimes teachers are accompanied with different stuffs as other human beings and many of them are brought by the school management, others brought by their personal life. So it is advised that they should be given the chance to attend different trainings for them to be updated and to know how they can figure their problems to help them concentrate with school matters to generate and improve their teaching performance.

Additionally, 13(15.47\%) affirmed that training of the workforce helped teachers to overcome various challenges that came about during the instructional process and thus improving teachers' effectiveness. Investing teachers with new knowledge and skills has proved with positive results that teachers are able to deal with different stuffs that are related to their career to make sure that those problems may not affect their performance.

Generally, these findings implied that teachers were equipped with knowledge and skills that were applicable in the learning and teaching process and which positively affected their job performance.

Thus, the aforementioned findings are in line with Harrison (2000) and Wright \& Geroy (2001) whose findings in a study regarding correlation between impacts of employee's training and employee's empowerment found out that there was a strong correlation between the two. Therefore the researcher confirmed that in deed training the teachers empower them with knowledge, skills, techniques and strategies that enhance their job performance.

Meanwhile, in order to obtain deep information on the effects of training the workforce so as to improve teachers' job performance, the researcher conducted an interview to the heads of public secondary schools and the DEO. The study demonstrated two major themes which emerged as the impact of teachers' training in schools in influencing teachers' job performance. Among those themes involves reducing staff turnover (teachers retention) and better performance from the employees (teacher). The themes are presented based on their emergence in the interviews.

\section{Better Performance from the Teachers}

Better performance from the teachers emerged as strong theme among the school heads and the DEO during the interview. It was denoted that, majority of the school heads who were the respondents in this study have to encourage and suggest for their teachers to be given the chance for further training for them to develop their teaching skills. In schools, they have to insure that every teacher has the chance to go for training courses. Talking on better performance from the teachers, a head of school D said that,

In my school I motivate teachers by providing rewards to the best teacher especially when they perform and produce good results in form four national examinations. And when a teacher continues with the same tendency is where I propose their names for the DEO for them to be sponsored to get the chance for further training (Hos, September 24, 2020).

Furthermore, the findings from the interview of the same theme indicated that, trained teachers are more willing to continue working in the same school after being trained than those who are not yet trained. Hence they confirm that, onworking training is a key factor to good performance. For instance, a head of school A stated that,

Once an employee is trained, he or she gains opportunity to enhance their performance, their current job has direct impact on achieving the school objectives, their job performance outcomes are consistent with the school goals and their job performance in general (Hos, September 24, 2020).

These findings are similar to that of Shah and Rehana (2011) in their study who revealed that, every community invests inside the teacher schooling by creating the teachers' perspective in training methodologies and ways of ensuring maximum outcomes through the system. In Pakistan key teacher's education is a pivotal thought of diverse national and also international companies. These institutions are 
continuously adding to develop the teachers' skills at fundamental level. That is to say, training for teachers is a vital aspect to develop and improve teachers' job performance.

Additionally, during the interview with the head of school B in the response to the same question added that,

I really want my teachers to go for further trainings to improve their working performances but they are not ready. Maybe, they are already satisfied with their levels of education and experience in teaching; even when they attend any seminar, they are motivated by the payment (Hos, September 24, 2020).

Analyzing the feelings of the head of school B, it could be established that some of the teachers probably who are about to get retired or those who are accompanied with couple of responsibilities to their families are not valuing the importance of going for further trainings. Meanwhile, during the interview with the District Education Officer (DEO), he also acknowledged that, "most teachers participate in different training programs so as to update and equip them with the necessary knowledge to enhance their job performance".

Generally, most of the interview with school heads (HOSs) revealed that in most cases the scheduled training programs focus to science teachers as compared to other categories. When asked to give reasons for the response, HOSs claimed that since the government put more emphasis on science subjects hence many training programs target science teachers so as to enhance their job performance. One HOS added that "the community around had a positive attitude with science subjects and students themselves were willing to join these subjects, hence we have community support in this area of subject".

\section{Teachers' Retention}

As it was indicated in quantitative data that, in most cases trainings for teachers reduces staff turnover. A similar theme emerged in interviews among the school heads. The findings indicated that, the more teachers are getting the chance for further trainings to increase their knowledge and skills of their teaching carrier is the more they wish to remain in the same organization/school. For instance, a head of school F spoke that,

After the form four national examinations results, evaluation of all subjects and questions is done through seminars and workshops. It includes seminars on strategies on how to teach different subjects. And after the seminar they are given the chance to volunteer for further training for them to develop skills got from those seminars (HoS, September 24, 2020).

Osaki (1996) noted that in-service training was a very important aspect, if it was not done regularly teachers would be out of date as they would they would be left behind to new subject knowledge and pedagogical skills. Akinbode (1996) conducted research in Nigeria on training and established that investment in the form of in-service training was a crucial factor in the development of job commitment. The result of the study showed that teachers who had low professional commitment prior to training became highly committed after they were given opportunity to go for training, the training served to boost their moral and thus lead to positive job performance among them.

\section{Effects of Performance Appraisal on Teachers' Job Performance}

The second research objectives sought to find out the effects of performance appraisal on teachers' job performance in public secondary schools. Questionnaires for teachers were used to collect data whereby teachers were required to rate the effects of performance appraisal on teachers' job performance. The respondents were required to rate the items on a scale of strongly agree, agree, uncertain, disagree and strongly disagree. The findings are summarized and presented in table 4.7.

Table 7: Effects of Performance Appraisals on Teachers' Job Performance $(n=84)$

\begin{tabular}{lcc}
\hline Ranking & Frequency & Percentage \\
\hline Strongly agree & 27 & 32.14 \\
Agree & 39 & 46.43 \\
Disagree & 9 & 10.71 \\
Strongly disagree & 7 & 8.33 \\
Uncertain & 2 & 2.39 \\
\hline Total & $\mathbf{8 4}$ & $\mathbf{1 0 0}$
\end{tabular}

Source: Field Data, (2020)

Findings presented in table 7 indicate that $39(46.43 \%)$ of teachers agreed while $27(32.14 \%$ ) of them strongly agreed that performance appraisal had impact on their job performance. On the other hand, 9(10.71\%) of the respondents disagreed, while $7(8.33 \%)$ strongly disagreed with the opinion that performance appraisal had impact on their job performance. However, only 2(2.39\%) of the 
participants pointed out that they are not aware on performance appraisal effects on their job performance.

Thus the study findings concluded that majority of teachers 66(78.56\%) were aware of the performance appraisal system and that they actually confirmed that performance appraisal enhanced their job performance. The aforementioned findings were in line with Rao (2009) who emphasized on the importance of subordinates involvement in the process of performance appraisal in an organization. Rao (2009) suggested that there should be an effective involvement of supervisors and employees in carrying out the Performance Appraisal in an organization.

Additionally, the findings were supported by Chambo (2008) study on management of performance appraisal programme in Tanzania. The purpose was to assess how performance appraisal programme was managed in Kwimba District. The results demonstrated that OPRAS was poorly performed. Some of the employees were not aware of the programme; no feedback regarding the performance was provided and that only one performance appraisal instrument accommodated for the whole council. Chambo advised that the government was supposed to employ more Human Resource personnel professionals in the public schools so as to improve the teachers' job performance in secondary schools.

On the other hand, the respondents (teachers) required to rate the items in a Likert scale indicating the extent to which they agreed or disagreed with the items given and their influence of performance appraisal on teachers' job performance. Results obtained were summarized and presented in the table 8.

Table 8: Influence of Performance Appraisals on Teachers' Job performance $(n=84)$

\begin{tabular}{|c|c|c|}
\hline Effect & Frequency & Percentage \\
\hline $\begin{array}{l}\text { Simplify supervision } \\
\text { process }\end{array}$ & 29 & 34.52 \\
\hline $\begin{array}{l}\text { Simplifies evaluation and } \\
\text { assessment process }\end{array}$ & 34 & 40.48 \\
\hline $\begin{array}{l}\text { Increases teacher's } \\
\text { creativeness in teaching }\end{array}$ & 11 & 13.10 \\
\hline $\begin{array}{l}\text { Helps in classroom } \\
\text { management }\end{array}$ & 10 & 11.90 \\
\hline Total & 84 & 100 \\
\hline
\end{tabular}

\section{Source: Field Data, (2020)}

Findings summarized and presented in table 8 indicate that majority of teachers, 34 (40.48\%), showed that performance appraisal influenced job performance through simplifying the evaluation and assessment process. This is because, the more performance appraisal is done in schools it generates the skills and more valuable ways of teaching strategies hence they can manage to improve their job performance.

Furthermore, $29(34.52 \%)$ of the teachers stated that performance appraisal influenced job performance through simplifying the supervision process. This is related to how system theory works. Teachers with the cooperation received from the head of schools helps them to update their working performance. This is done through instructional supervision and day to day follow-ups concerning their teaching progressive.

However, only $11(13.10 \%)$ of the teachers indicated that performance appraisal influenced job performance through increasing teachers' creativeness in teaching and only 10 (11.90\%) of the sampled teachers that stated that performance appraisal influenced job performance through helping in classroom management as indicated in table 8 .

In order to confirm the above findings in-depth information concerning the effects of performance appraisal on teachers' job performance, the researcher conducted six interviews to the head of public secondary schools and one interview to DEO. Results from Head of Schools (HOSs) and District Education Officer (DEO) indicated that performance appraisals do affect teachers' job performance in various ways including; improving overall personnel performance, simplifying supervision process, ensuring teachers' discipline, improving proper communication and helping in classroom management. Thus, the head of schools and District Education Officer confirmed that performance appraisals do affect teachers' job performance in ways explained below and as transcribed from the interviews conducted.

\section{Improved Overall Teacher's Personnel}

Improved overall teacher's personnel emerged as strong theme among the effects of performance appraisal on teachers' job performance in the interview. Most of the head of schools interviewed asserted that, whenever performance appraisal was practiced regularly, there was great possibility for the teachers to develop and grow as an individual in all aspects of teaching career. Speaking about improving overall personnel, a head of school D said that;

First of all, I ensure that teachers are encouraged to set their goals by develop their strategic and action plans, scheme of works, $\log$ books and filling them accordingly before the start of the academic 
year. Through those actions, every teacher is punctual because he or she cannot proceed with teaching before the assessment of those materials (Head of school D, September 14, 2020).

The quotation above indicate that, school heads as human resource managers in school level are always playing a huge role in molding teachers' future by guiding them in preparing different teaching materials and use them in accordance with the syllabus to make sure that students are getting the quality education as required.

\section{Simplifying Supervision Process}

It was reported that, majority of the school heads who participated in this study promote proper supervision in school settings. They ensure that, the school timetable is abided by teachers as scheduled. Speaking about simplifying supervision process, a head of school $\mathrm{C}$ spoke that,

In my school, I ensure that all teachers do follow the school calendar and timetable. The school timetable shows daily duties of each teacher and the time of exercising such activities while the school calendar shows the date and day where different events will be exercised within a particular year (Head of school C, September 17, 2020).

The quotation above indicate that, school heads as human resource managers in school setting are ensuring that all teachers do follow and respect all the tasks assigned so that school mission and vision are met.

\section{Helping in Classroom Management}

Also this is another theme emerged during the interview with the school heads. It was found that, through performance appraisal, teachers are being helped on improving the skills on classroom management during the teaching process. Speaking about the classroom management, a head of school B said that, "....in my school, I insist teachers to be punctual in their respective classes. I make sure that, they are able to teach by using participatory methods and being able to manage the class accordingly" (Head of school B, September 18, 2020). Responding to the same question another school head argued that, teachers are being enabled to teach and use all the teaching aids and all the required materials appropriately. He also claimed that, teachers carry out their duties because they are provide with instructional materials. For example a head of school E spoke that,
"In my school I normally enable teachers to teach accordingly by providing them with teaching materials like; chalks, marker pen, manila cards as well as chemicals for science teachers and by doing that, teachers are motivated to use teaching aids as it is required" (Head of school E, September 21, 2020). Also the interview with the DEO, evidenced the issue of classroom management through performance appraisal when he said,

I encourage school heads to make sure that every teacher has to prepare all the materials required by setting clear expectations before entering the classroom so that students must be engaged in the respective lesson when the teacher is teaching (DEO, September 23, 2020).

The quotations above denote that, performance appraisal in secondary schools is very essential for enhancing students' academic achievements and influencing teachers' job performance respectively. Therefore, the findings of this study imply that, there was a consensus of ideas in the quantitative and qualitative data concerning the influence of employee development practices particular with performance appraisal on teachers' job performance especially in the issue of classroom management.

\section{CONCLUSION}

The study concluded that training plays a greater role on teachers' job performance and that there was a need for continuous training for public secondary school teachers. Also performance appraisals should be conducted frequently in secondary schools as they upgrade the teachers' performance. Performance appraisal helped in various ways including simplifying the supervision process, simplifying the evaluation and assessment process, increasing teachers' creativeness in teaching, and classroom management. All these brought about improvement on teachers' job performance.

\section{RECOMMENDATIONS}

Based on the findings of this study, the following recommendations were made;

Ministry of Education, Science and Technology in conjunction with district education administrators should make sure they set up a budget for in-service trainings and workshops for teachers as well as organize and facilitate inservice trainings and seminars. 
In addition, heads of schools should make sure they disseminate timely information regarding national, regional and local in-service training for the teachers as well as make sure that teachers attend such programs.

On the other hand, school administrators together with the heads of public secondary schools should take adequate measures to ensure that the newly employed teaching staffs are given proper orientation, induction and in-services training to enhance their productivity

\section{REFERENCES}

[1] Ahn, C., Heo, M., \& Zhang, S. (2015). Sample size calculations for clustered and longitudinal outcomes in clinical research. Retrieved from https://www.crcpress.com/Sample-Size-Calculations-forClustered-and-Longitudinal-Outcomes-in-Clinical/Ahn-HeoZhang/p/book/9781466556263

[2] Alsaaty, F. M., \& Morris, A. (2011). High school leadership: The challenge of managing resources and competencies. Journal of Case Studies in Education, Vol 3(8), pp 1-12.

[3] Ary, D., Jacobs, L.C., \& Sorensen, C. (2010). Introduction to research in education ( $8^{\text {th }}$ ed.). USA, Wadsworth Cengage Learning.

[4] Bailey, C. A. (2007). A guide to qualitative field research (2 ${ }^{\text {nd }}$ ed.). New Delhi: Pine Forge Press.

[5] Benedict, G. S. (2012). The human resources management (HRM) practices a panacea to the challenges of the ministry for home affairs in South Africa. Retrieved from http://uir.unisa.ac.za/bitstream/10500/6534/3/2012\%20MBA \%20Research\%20Report\%20SB\%20Gamedze.pdf.txt

[6] Blessing, L.T.M., \& Chakrabarti, A. (2009). DRM, a design research methodology. Springer: London.

[7] Byars, L. L., \& Rue, L. W. (2006). Human Resource Management. Retrieved from https://trove.nla.gov.au/work/5486330

[8] Cargan, L. (2007). Doing social research. United State of America, USA: Row Man and Little Field Publishers, Inc.

[9] Chemutai, E. (2017). Solution to the challenges facing school principals as human resource managers (HRM) in secondary schools in Nandi County, Kenya. Africa International Journal of Multidisciplinary Research, 1(2), 1-6.

[10] Creswell, J. W. (2012). Educational Research: Planning, Conducting, and evaluating quantitative and qualitative research ( $4^{\text {th }}$ ed.). Boston: Pearson.

[11] Creswell, J. W. (2014). Research design: A qualitative, quantitative and mixed method approaches ( $4^{\text {th }}$ ed.). Washington, DC: SAGE.

[12] Cunningham, J. B. (2016). Strategic human resource management in the public arena: a managerial perspective. United Kingdom: Palgrave.

[13] Drenna, R. D. (2009). Statistical for archaeologists: A common sense approaches $\left(2^{\text {nd }}\right.$ ed.). New York. NY: Springer.
[14] Duze, C. O. (2012). The Changing role of school leadership and teacher capacity building in teaching and learning. Journal of Emerging Trends in Educational Research and Policy Studies, Vol 3 (1), pp. 111-117.

[15] Festus, A., Valentine, O., \& Esther, M. (2019). Human resource management and teachers' job performance in secondary schools in Akamkpa local government area of cross river state, Nigeria. International Journal of Social Sciences and Management Research, Vol 2(5), pp. 27-34.

[16] Ghauri, P., \& Gronhaug, K. (2005). Research methods in business studies: A practical guide ( $3^{\text {rd }}$ ed.). UK: Pearson Education, Inc.

[17] Graham, K., Hudson, P., \& Willis, J. (2014). How can principals enhance teachers' job satisfaction and work commitment? (Paper presented at the Australian Association of Research in Education). Retrieved from https://eprints. Qut. Edu. Au / 80087/1/-staffhome

[18] Groves, R. M., Fower, F. J., Couper, M. P., Lepkowski, J. M., Singer, E., \& Tourangeau, R. (2009). Survey methodology $\left(2^{\text {nd }}\right.$ ed.). Canada: John Wiley \& Sons, Inc.

[19] Hashmi, K. (2014). Human resource management strategies and teacher's efficiency within schools: A co-relational study. The IAFOR Journal of Education, Vol 1(2), pp. 65-87.

[20] Hunter, R., \& Dantzker, M. (2012). Research method: For criminology and criminal justice ( $3^{\text {rd }}$ ed.). USA: Cathleen Sether.

[21] Israel, (2013).Essential of Planning and Evaluation for Public Wealth: USA Sones Battelt Publishers.

[22] Jha, A. (2014). Social research methods. New Delhi: McGraw hill education private limited.

[23] Johnson, B., \& Christensen, L. (2012). Educational research: Quantitative, qualitative and mixed approach. New Delhi: SAGE public, Inc.

[24] Jugenheimer, D. W., Kelley, L. D., Hudson, J., \& Bradley, S. (2014). Advertising and Public Relations Research 2nd Edition. $\quad$ Retrieved from https://www.amazon.com/Advertising-Public-RelationsResearch-Jugenheimer/dp/0765636069

[25] Kajiru, J. J. (2014). The effectiveness of human resource strategies in local government authorities: A case of Babati District Council. Retrieved from http://repository. out.ac.tz/552/1/DISSERTATION_-_Kajiru_-25-11-2014.pdf

[26] Klenke, K. (2016). Qualitative research in the study of leadership ( $2^{\text {nd }}$ ed.). UK: Emerald Group Publishing Limited.

[27] Kothari, C.R. (2004). Research methodology: methods and techniques. New Delhi: Sage.

[28] Krauss, G. S. (2009). Partner departures and lateral moves: A legal and ethical guide. United State of America, USA: American Bar Association.

[29] Kumar, R. (2005). Research methodology: a step by step for beginners. New Delhi: Sage.

[30] Kumar, R. (2011). Research methodology, a step quid for beginners ( $3^{\text {rd }} e d$.). Loss Angeles. SAGE Publication Ltd. 
[31] Leary, M.R. (2004). Introduction to behavior research methods. Boston: Pearson.

[32] Ludwing, V.B. (1956). The social system theory. Cologne CBs Publishers.

[33] Lunenburg, C. F. (2010). School as an open system. Sann Houston, State University. Electronic Journal volumes/Lunenburg. Fred C schools as an open systems, Vol (1), pp. 1-5.

[34] Mele, C., Peles, J., \& Polese, F. (2010). A brief review of system theories and their managerial application. Service science 2 (1-2): 126-135. https:// doi. Org/ 10. 1287/ serv. 2. 12. 126.

[35] Mitaru, G. M. (2015). Barriers to effective human resource management faced by public primary school head teachers: Mwea East Sub-County, Kirinyaga County- Kenya. Retrieved from

https://pdfs.semanticscholar.org/4287/6db8b34a7d0e2aebf2ff 0d48c4128 b297687.pdf

[36] Muhoho, J. (2014). Challenges facing human resource succession planning in Tanzania's work organizations: The case of public and private work organizations based in Dar es Salaam region. International Journal of Innovation and Scientific Research, Vol 12(1), pp. 232-247.

[37] Muthoni, N. J. (2015). Effectiveness of secondary school principals in management of human resource: A case of Mathioya District, Murang'a County, Kenya. Retrieved from http://ir-library.ku.ac.ke/bitstream/handle/123456789/10889

[38] Mutinda, K.P. (2015). Challenges facing board of managers in the management of public secondary schools; Kamwangi District, Kenya. Merit Research Journal of Education and Review, Vol 3 (9), pp. 1-5.

[39] Narkhede, A., \& Joshi, S. P. (2014). Challenges of human resources management in borderless world. Global Journal of Business Management, Vol 3(1), pp. 167-173.

[40] National Bureau of Statistics (2012). The map of Nyamagana district. $\quad$ Retrieved from https://www.citypopulation.de/php/tanzania-lake-adminphp?admlid=2403

[41] Ndikumana, E. D. (2018). The role of human resource management practices in the migration of medical doctors in developing countries: The case of Tanzania. Retrieved from http://scholar.mzumbe.ac.tz/handle/11192/2308

[42] Okumbe, J. A. (1998). Education management theory and practice. Nairobi: university press.

[43] Oluwakemi, A., \& Olanrewaju, A. (2014). Counterproductive behavior and job performance among secondary school teachers: School climate as a mediator. Journal of Education and Practice, Vol 5(8), pp. 198-204.

[44] Omebe, C. A. (2014). Human resource management in education: Issues and challenges. British Journal of Education, $7(2), 26-31$.

[45] O'riordan, J. (2017). Practice of human resource management that appears to contribute mostly on improving productivity to an organization in Ireland. Retrieved from
https://www.ipa.ie/_fileUpload/Documents/THE_PRACTICE _OF_HRM.pdf

[46] Orodho, A., \& Kombo, D. (2002). Research methods. Kenyatta University, Institute of Open Learning, Nairobi.

[47] Paschal, M. J. \& Mkulu, D. G. (2020). Online Classes during COVID-19 Pandemic in Higher Learning Institutions in Africa. Global Research in Higher Education 3(3), 1-21. DOI: https://doi.org/1022158/grhe.v3n3p1

[48] Paschal, M. J. \& Mkulu, D. G. (2020). Teacher- Students' Relationship and Students 'Academic Performance in Public Secondary Schools in Magu District, Tanzania. Journal of Research in Education and Society, 11(1), 20-3. http://www.icidr.org/jresv11no1-content.php.

[49] Paschal, M. J., Nyoni. T. T. \& Mkulu, D. G. (2020). The Role of Cooperative Learning in Attaining Inclusive Learning in the Classroom, Creativity and Innovation in Secondary Schools in Mwanza Region - Tanzania. International Journal of English Literature and Social Sciences, (IJELS), 5(2). http://journalrepository.com/index.php/ijels/article/view/1730

[50] Picardi, C. A., \& Masick, K. D. (2014). Research methods: Designing and conducting research with a real-world focus. Washington, DC: SAGE publications, Inc.

[51] Ramadhani, R. M. (2017). The effects of human resource management practices on employees' job satisfaction in Monduli district council. Retrieved from http://repository. out.ac.tz/1989/1/RAMAZAN\%202017\%20REPORT2\%203.p df

[52] Ravitch, S. M., \& Riggan, M. (2012). Reason and rigor: How conceptual framework guide research. New Delhi: SAGE Publication, Inc.

[53] Rubin, A., \& Babbie, E. (2010). Essential research methods for social work $\left(2^{\text {nd }}\right.$ ed.). United Kingdom: CENGAGE Learning.

[54] Runhaar, P. (2016). Education management administration and leadership. SAGE Journals, 6(93), 8-15.

[55] Saifalislam, K. M., Osman, A., \& AlQudah, M. K. (2014). Human resource management practices: Influence of recruitment and selection, and training and development on the organizational performance of the Jordanian Public University. IOSR Journal of Business and Management, Vol 5(16), pp. 4346.

[56] Saunders, N. K., Lewis, P., \& Thornhil, A. (2009). Research methods for business students (5th Edition). Retrieved from https://www.amazon.com/Research-Methods-BusinessStudents-5th/dp/0273716867

[57] Scott, W. R. (2008). Institutions and organizations: Ideas and interests. UK: Sage.

[58] Selamat, N., \& Samsu, N. S. (2013). The impact of organizational climate on teachers' job performance. Educational Research, Vol 1(2), pp.71-82.

[59] Shulky, A. N \& Schmitt, G. J. (2011). Silent warfare: Understanding the world of intelligence. Washington, D.C: Potomac Books, Inc. 
[60] Siameto, D. S. (2017). Influence of human resource management practices on teachers' commitment in public secondary schools in Narok North Sub-county: A case of teachers' service commission. Retrieved from http:// erepository. uonbi.ac. ke:8080/ handle/11295/ 101386

[61] Takeuchi, R., Lepak, D.P., Wang, H. \& Takeuchi, K. (2007). An empirical examination of the mechanisms mediating between high-performance work systems and the performance of Japanese organizations. Journal of applied psychology Vol 2(9), pp.1069-1083.

[62] Tan, C. L. \& Nasurdin, A. M. (2011). Human resource management practices and organizational innovation: Assessing the mediating role of knowledge management effectiveness in Malaysia. Electronic Journal of Knowledge Management, Vol 2(9), pp. 155-167.

[63] Thien, L. M., Razak, N. A., \& Hazri, J. (2012). Friendship Quality Scale: Conceptualization, Development and Validation. Retrieved from https://eric.ed.gov/?id=ED542465

[64] Wanjara, D. N., Wamalwa, R. W., \& Egessa, R. (2014). Effect of selected human resource practices on teachers' performance in public primary school: A case study of Bungoma west sub-county. International Journal of Social Sciences and Entrepreneurship, Vol 11(1), pp. 1-11.

[65] Waseem, S. N., Frooghi, R., \& Afshan, S. (2013). Impact of human resource management practices on teachers' performance: A mediating role of monitoring practices. Journal of Education and Social Sciences, 1(2), 31-55.

[66] Watson, J. C., \& Flamez, B. (2015). Counseling assessment and evaluation: Fundamentals of applied practice. New Delhi: SAGE Publication, Inc. 